\title{
Effects of Dietary Herbal Antioxidants Supplemented on Feedlot Growth Performance and Carcass Composition of Male Goats
}

\author{
${ }^{1,5}$ Morteza Karami, ${ }^{1,3}$ Abd Razak Alimon, ${ }^{2}$ Yong Meng Goh, ${ }^{1}$ Awis.Qurni Sazili and ${ }^{3,4}$ Michael Ivan \\ ${ }^{1}$ Department of Animal Science, University Putra Malaysia, \\ 43400 UPM Serdang, Selangor, Malaysia \\ ${ }^{2}$ Department of Veterinary Preclinical Sciences, \\ University Putra Malaysia, 43400 UPM Serdang, Selangor, Malaysia \\ ${ }^{3}$ Institute of Tropical Agriculture, University Putra Malaysia, \\ 43400 UPM Serdang, Selangor, Malaysia \\ ${ }^{4}$ Dairy and Swine Research and Development Centre, Agriculture and Agri-Food Canada, \\ 2000 College Street, PO Box 90 STN Lennoxville, Sherbrooke, Quebec, Canada J1M 1Z3 \\ ${ }^{5}$ Department of Animal Science, Agriculture and Natural Resource Research Centre, 415, Shahrekord, Iran
}

\begin{abstract}
Problem statement: In goats production, chevon, meat quality and shelf life are very important, dietary herbs and synthetic antioxidants as dietary supplementation, may be can improve growth performance and carcass characteristics of goats. Approach: Thirty-two male (mean live weight $13.0 \mathrm{~kg}$ and 8 months old) were assigned to four dietary treatments, namely, basal diet (control, $\mathrm{CN}$ ) and basal diet supplemented with Vitamin E (VE), Turmeric powder (TU) or Andrographis paniculata Powder (AP). The diets were fed as total mixed rations ad libitum for a period of 14 weeks. The goats were weighed every month, while feed intake was measured on a weekly basis. Thereafter, the goats were subjected to the Halal slaughter and the carcasses dissected. Result: The daily weight gain was not different $(p>0.05)$ between treatments, but the feed intake was lower $(p<0.05)$ for the AP treatment than for the TU treatment, while the gain: DM intake was lower $(\mathrm{p}<0.05)$ for the $\mathrm{CN}$ treatment than for the AP treatment. The percentage of total meat in the carcass and the longissimus muscle cut were higher $(\mathrm{p}<0.05)$ for the AP treatment than for the $\mathrm{CN}$ treatment. Conclusion: It was concluded that dietary antioxidants from natural herbs such as Andrographis paniculata have the potential to improve feed efficiency, increased lean meat and reduced body internal fat in the carcass of goats. Addition of TU increased Average Daily Gain (ADG) and feed intake.
\end{abstract}

Key words: Growth performance, goat carcass characteristics, vitamin E, Andrographis paniculata, Turmeric

\section{INTRODUCTION}

The goat is an important source of animal protein for humans in warm climates (Kirton, 1988) and the meat (chevon) from local breeds is sought after in many parts of the world (Devendra and Burns, 1983). However, the declining profitability of traditional livestock production systems is a major challenge to farmers (Lupton et al., 2008). In many areas of Europe and Asia demand for chevon is higher than the local availability (Alexandre et al., 2008) and there is an urgent need to increase goat meat production in the tropics (Almeida et al., 2006; Phengvichith and Ledin, 2007). Antioxidants play an important role in animals as modulators of the immune system and protectors against oxidative damages and are important for the proper function of body enzymes (Sharma, 1976; Chew, 1995).Vitamins $\mathrm{C}$ and $\mathrm{E}$ are common antioxidants normally included in animal diets. Previous research suggested that relatively high levels of supplemental vitamin E (megadose) may improve carcass quality (McDowell et al., 1996) by reducing the oxidation of meat (Buckley et al., 1995; Morrissey et al., 1998; Webb et al., 2005; Dhanda et al., 2003). Saker et al. (2004) demonstrated that dietary inclusion of brown seaweed (TascoTM) improved function in heat-stressed lambs. Miquel et al. (2002) suggested that the turmeric antioxidants are active one step above that of vitamin $\mathrm{E}$

Corresponding Author: A.R. Alimon, Department of Animal Science, Institute of Tropical Agriculture,

University Putra Malaysia, 43400 UPM Serdang, Selangor, Malaysia

Tel: +603-89466891 Fax: +603-89432954 
and are stronger compared to vitamins $\mathrm{C}$ and $\mathrm{E}$ (Toda $e t$ al., 1985). Bioactive constituent in Curcumin longa are diterpen aldehyde curcuminoids, curcumin I, II and III as antioxidant (Toda et al., 1985; Rubya et al., 1995). Herbs that are known to have antioxidant activities have been used to replace vitamin E. These included carotenoids and other plant pigments, which have been shown to improve growth performance of livestock through increased immune status (Gupta and Taneja, 1983). Mishra et al. (2007) reported that Andrographis paniculata promoted digestion and its relaxing and restful herb. Andrographis paniculata Nees contain anderographolid and neoandrographolide, which are the bioactive diterpene lactones, which reduced the levels of the lipid oxidation product Malondialdehyde (MDA) in blood and tissue. They suggested that inhibition of malondialdehyde formation revealed the free radical scavenging properties of diterpene lactones (Zhang and Tan, 2000; Kamdem et al., 2002; Mishra et al., 2007; Jarukamjorn and Nemoto, 2008). Studies on the effects of local herbal plants as sources of dietary antioxidant on growth and carcass composition of goats are scarce (Colomer-Rocher et al., 1992; Farid, 1991). It is hypothesized that dietary antioxidant supplementation would improve feedlot performance and carcass characteristics of goats (Kosum et al., 2003). Consequently, the objective of the present study was to determine the effects of antioxidants (vitamin E and Rographis paniculata powder and turmeric powder) on the feedlot growth performance and carcass composition of the local Kacang goats.

\section{MATERIALS AND METHODS}

Animals and management: The study was undertaken following the guidelines of the Research Policy of the University Putra Malaysia on animal ethics. Thirty-two male goats $(13.0 \pm 0.3 \mathrm{~kg}), 8$ months old, were treated against internal and external parasites and used in an experiment lasting 16 weeks, including a 2 weeks adaptation period. Goats were housed individually $1.3 \times 0.9 \mathrm{~m}$ pens. The goats were assigned to four experimental groups of eight animals each. Each group was fed one of the four isocaloric and isonitrogenous diets (Table 1): (1) basal diet-control (CN), (2) basal + vitamin $\mathrm{E}$ (VE; $400 \mathrm{mg}$ per kg of dietary dry matter), (3) basal $+0.5 \%(w / w)$ of turmeric (Curcumin longa) powder (TU) and (4) basal $+0.5 \%(\mathrm{w} / \mathrm{w})$ of Andrographis paniculata Powder (AP). The A. paniculata was harvested and processed in the early blooming stage as described by Tipakorn et al. (2003). The whole plant was oven dried at $49^{\circ} \mathrm{C}$ for $72 \mathrm{~h}$ and ground to pass a $3 \mathrm{~mm}$ sieve, packed in airless plastic bags and kept in a cool place. Food-grade pure turmeric powder $(100 \%)$ was purchased from the Baba's Products Sdn Bhd, Kuala Lumpur, Malaysia. Vitamin E was dl- $\alpha$-tocopheryl acetate (BASF, Lutavit, Germany). The diets were prepared weekly as total mixed rations and animals consumed diets ad libitum daily. The goats were weighed monthly Feed intakes and feed refusals were collected and recorded daily.

Table 1: Composition of diets fed to goats in different treatments: (1) basal diet-Control (CN), (2) basal + Vitamin E (VE), (3) basal + Turmeric (TU) and (4) basal + Andrographis Paniculata (AP)

\begin{tabular}{|c|c|c|c|c|c|}
\hline \multirow[b]{2}{*}{ Ingredients (as fed) } & \multicolumn{5}{|c|}{ Treatments } \\
\hline & $\mathrm{CN}$ & VE & TU & $\mathrm{AP}$ & SEM \\
\hline Palm kernel cake (\%) & 27.00 & 27.00 & 27.00 & 27.00 & \\
\hline Oil palm frond (\%) & 30.00 & 30.00 & 29.50 & 29.50 & \\
\hline Soybean $(\%)$ & 13.10 & 13.10 & 13.10 & 13.10 & \\
\hline Corn grain milled (\%) & 12.00 & 12.00 & 12.00 & 12.00 & \\
\hline Rice bran $(\%)$ & 14.00 & 14.00 & 14.00 & 14.00 & \\
\hline Oil (\%) & 2.40 & 2.40 & 2.40 & 2.40 & \\
\hline Limestone (\%) & 0.50 & 0.50 & 0.50 & 0.50 & \\
\hline Salt $(\%)$ & 0.40 & 0.40 & 0.40 & 0.40 & \\
\hline Mineral premix (\%) & 0.50 & 0.50 & 0.50 & 0.50 & \\
\hline Vitamin E (IU) ${ }^{1}$ & - & 400.00 & - & - & \\
\hline Turmeric $(\%)$ & - & - & 0.50 & - & \\
\hline Andrographis paniculata (\%) & - & - & - & 0.50 & \\
\hline \multicolumn{6}{|l|}{ Chemical composition } \\
\hline Dry matter (DM) (\%) & 91.90 & 91.30 & 91.80 & 91.90 & 0.30 \\
\hline Crude protein $(\%)$ & 14.60 & 14.60 & 14.50 & 14.60 & 0.10 \\
\hline Metabolizable energy (Mcal kg-1 DM) & 2.40 & 2.40 & 2.40 & 2.40 & - \\
\hline Ash $(\%)$ & 8.39 & 8.50 & 8.45 & 8.12 & 0.30 \\
\hline Ether extract $(\%)$ & 3.69 & 3.91 & 3.55 & 3.45 & 0.18 \\
\hline Neutral detergent fiber $(\%)$ & 48.50 & 49.20 & 49.30 & 49.40 & 1.90 \\
\hline Acid detergent fiber $(\%)$ & 33.90 & 34.20 & 34.50 & 34.40 & 0.60 \\
\hline
\end{tabular}

${ }^{1}:$ DL- $\alpha$ - tocopherole acetate $400 \mathrm{mg} \mathrm{kg}^{-1}$ dry matter intake 
Feed nitrogen was determined using the automated Kjeldahl (2400 Kjeltec, Analyzer Unit, Foss Tecator, Sweden) and fat as ether extract using the Soxhelt method (2050 Soxtec, Auto Extraction, Foss Tecator, Sweden). Dry Matter (DM) was determined by drying at $100^{\circ} \mathrm{C}$ and ash by incineration in furnace at $550^{\circ} \mathrm{C}$ (AOAC, 1990).

Carcass characteristics: After feeding the experimental diets for 14 weeks (end of the experiment), all goats were weighed following an overnight fast and subjected to the Halal slaughter at the University Research Abattoir. An empty warm carcass weight was obtained after pelting, evisceration and severance of head and feet. Internal fat tissues, which internal fat included peritoneal and mesenteric, kidney, heart and channel fats depots, were weighed separately. The carcass was then chilled for $24 \mathrm{~h}$ at 2$32^{\circ} \mathrm{C}$. Post chilling carcass weight was recorded $24 \mathrm{~h}$ post mortem and then the carcass was split into two equal, left and right, halves using an electric saw. The right half carcass was weighed and then cut into five primal cuts (Fig. 1): neck, shoulder, breast-flank, loin and leg. The cuts were weighed and expressed as a percentage of the total weight of the right half carcass.

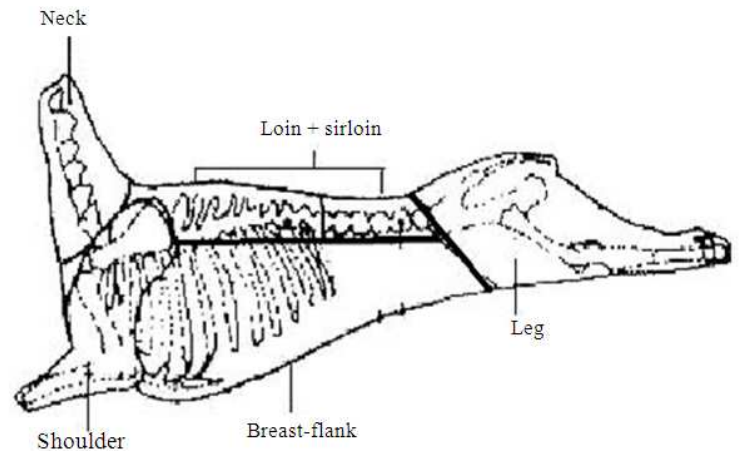

Fig. 1: Different cuts of goat carcass
Each cut was dissected into components of lean meat, bone, subcutaneous fat and intermuscular fat. The thickness of subcutaneous adipose tissue fat (over the 12-13 rib) and the length and depth of Longissimus dorsi muscle were measured with a digital caliper. The Longissimus muscle area (Bock et al., 1991) was determined from the tracing paper using two-dimension polygons area calculator software (Branscome and Jesseman, 1999).

Statistical analysis: The experiment was a completely randomized design. Individual animal was the experimental unit. Body weight and carcass weight, dressing percentage and composition were analyzed using the GLM procedure of Statistical Analysis System package (SAS) ver. 9.1 (SAS Institute Inc. Cary, NC). The initial weight and hot carcass were used in the model as covariate, because they had significant effect on some variables. When covariance was not significant, it was removed from the model. Average Daily weight Gain (ADG), FCR and FE were analyzed using the MIXED procedure of SAS with time as a repeated measure. Most interactions between treatment and time were no significant and, thus, were not reported. Differences were considered significant at $\mathrm{p}<0.05$.

\section{RESULTS}

Growth performance: The mean initial and final weights of goats (mean \pm standard error) were 13.0 \pm 0.3 and $22.2 \pm 0.5 \mathrm{~kg}$, respectively. The final weights and the daily weight gains were lowest for the $\mathrm{CN}$ treatment and highest for the TU treatment, but the differences between treatments were not significant (Table 2). Daily feed intake was lower $(\mathrm{p}<0.05)$ for the AP treatment $(661 \pm 21 \mathrm{~g})$ than for the $\mathrm{TU}$ treatment $(737 \pm 25 \mathrm{~g})$. Similarly, the dry matter Feed Efficiency (FE) was higher $(\mathrm{p}<0.05)$ for the AP treatment than for the $\mathrm{CN}$ treatment, but the differences between $\mathrm{CN}$ and VE treatments were not significant.

Table 2: Growth performance of goats in different treatments: (1) basal diet-Control (CN), (2) basal + Vitamin E (VE), (3) Basal + Turmeric (TU) and (4) basal + Andrographis Paniculata (AP)

Treatments

\begin{tabular}{|c|c|c|c|c|c|c|c|c|}
\hline \multirow[b]{2}{*}{ Parameter } & \multicolumn{2}{|l|}{$\mathrm{CN}$} & \multicolumn{2}{|l|}{ VE } & \multicolumn{2}{|l|}{ TU } & \multicolumn{2}{|r|}{ AP } \\
\hline & Mean & SE & Mean & SE & Mean & SE & Mean & SE \\
\hline Initial weight $(\mathrm{kg})$ & 13.00 & 0.60 & 12.90 & 0.60 & 13.40 & 0.70 & 13.00 & 0.60 \\
\hline Final weight $(\mathrm{kg})$ & 21.40 & 1.10 & 21.70 & 1.10 & 23.60 & 1.20 & 22.50 & 1.10 \\
\hline Daily feed intake $\left(\mathrm{g} \mathrm{day}^{-1}\right)$ & $726.00^{\mathrm{ab}}$ & 21.00 & $722.00^{\mathrm{ab}}$ & 21.00 & $737.00^{\mathrm{a}}$ & 25.00 & $661.00^{\mathrm{b}}$ & 21.00 \\
\hline Average daily gain $\left(\mathrm{g} \mathrm{day}^{-1}\right)$ & 84.80 & 7.30 & 87.90 & 7.30 & 101.90 & 7.30 & 95.90 & 7.30 \\
\hline Feed: Gain ratio (As-fed) & $9.06^{\mathrm{a}}$ & 0.39 & $8.74^{\mathrm{a}}$ & 0.39 & $7.49^{\mathrm{b}}$ & 0.38 & $7.16^{\mathrm{b}}$ & 0.38 \\
\hline Gain: DM intake $(\%)$ & $14.50^{\mathrm{a}}$ & 0.67 & $14.70^{\mathrm{ab}}$ & 0.67 & $16.40^{\mathrm{ab}}$ & 0.68 & $16.70^{\mathrm{b}}$ & 0.68 \\
\hline
\end{tabular}

${ }^{a, b}$ : Means within rows with different superscripts are different $(\mathrm{p}<0.05) ;{ }^{1}:$ Gain: Dry matter intake or feed efficiency 
American J. Animal \& Vet. Sci., 5 (1): 33-39, 2010

Table 3: Carcass composition of goats in different treatments: (1) basal diet-Control (CN), (2) basal + Vitamin E (VE), (3) basal+ Turmeric (TU) and (4) basal + Andrographis Paniculata (AP)

\begin{tabular}{|c|c|c|c|c|c|c|c|c|}
\hline \multirow[b]{3}{*}{ Parameter } & \multicolumn{7}{|c|}{ Treatments } & \multirow[b]{2}{*}{ AP } \\
\hline & \multicolumn{2}{|l|}{$\mathrm{CN}$} & \multicolumn{2}{|l|}{ VE } & \multicolumn{2}{|l|}{$\mathrm{TU}$} & \multirow[b]{2}{*}{ Mean } & \\
\hline & Mean & $\mathrm{Se}$ & Mean & $\mathrm{Se}$ & Mean & $\mathrm{Se}$ & & $\mathrm{Se}$ \\
\hline Hot carcass (kg) & 10.30 & 0.40 & 10.40 & 0.50 & 11.30 & 0.50 & 10.70 & 0.40 \\
\hline Cold carcass (kg) & 10.10 & 0.40 & 10.20 & 0.40 & 10.60 & 0.40 & 10.50 & 0.40 \\
\hline Cold carcass (\%) & 45.30 & 1.10 & 48.30 & 1.10 & 45.90 & 1.10 & 45.10 & 1.10 \\
\hline Dressing out $(\%)$ & 47.40 & 1.20 & 49.90 & 1.20 & 47.40 & 1.20 & 46.70 & 1.20 \\
\hline Mesentery fat (\%) & $1.55^{\mathrm{ab}}$ & 0.18 & $1.40^{\mathrm{ab}}$ & 0.18 & $1.71^{\mathrm{a}}$ & 0.18 & $1.16^{\mathrm{b}}$ & 0.18 \\
\hline Kidney fat $(\%)$ & $0.87^{\mathrm{ab}}$ & 0.12 & $0.67^{\mathrm{ab}}$ & 0.12 & $0.98^{\mathrm{a}}$ & 0.12 & $0.64^{\mathrm{b}}$ & 0.12 \\
\hline Heart fat $(\%)$ & 0.18 & 0.03 & 0.20 & 0.03 & 0.22 & 0.03 & 0.21 & 0.03 \\
\hline Channel fat (\%) & 0.28 & 0.06 & 0.34 & 0.06 & 0.38 & 0.06 & 0.26 & 0.06 \\
\hline Total meat $(\mathrm{kg})^{1}$ & $3.03^{\mathrm{a}}$ & 0.13 & $3.40^{\mathrm{ab}}$ & 0.14 & $3.46^{\mathrm{b}}$ & 0.14 & $3.44^{\mathrm{b}}$ & 0.13 \\
\hline Total meat $(\%)^{1}$ & $63.40^{\mathrm{a}}$ & 1.40 & $65.20^{\mathrm{ab}}$ & 1.40 & $64.60^{\mathrm{ab}}$ & 1.40 & $67.80^{\mathrm{b}}$ & 1.40 \\
\hline Total bone $(\mathrm{kg})^{1}$ & 1.02 & 0.06 & 0.96 & 0.06 & 1.04 & 0.06 & 1.00 & 0.06 \\
\hline Total bone $(\%)^{1}$ & 21.00 & 1.10 & 19.20 & 1.10 & 19.30 & 1.10 & 20.00 & 1.10 \\
\hline Total subcutan. fat $(g)^{1}$ & 141.00 & 3.00 & 116.00 & 3.00 & 162.00 & 3.00 & 132.00 & 3.00 \\
\hline Total subcutan. fat $(\%)^{1}$ & 2.95 & 0.42 & 2.18 & 0.42 & 3.19 & 0.42 & 2.21 & 0.42 \\
\hline Total intermusc. fat $(\mathrm{g})^{1}$ & $172.00^{\mathrm{ab}}$ & 18.00 & $173.00^{\mathrm{ab}}$ & 18.00 & $196.00^{\mathrm{a}}$ & 18.00 & $144.00^{\mathrm{b}}$ & 18.00 \\
\hline Total intermusc. fat $(\%)^{1}$ & 3.87 & 0.34 & 3.45 & 0.34 & 3.69 & 0.34 & 3.12 & 0.34 \\
\hline Neck $(\%)$ & 13.00 & 0.50 & 12.80 & 0.50 & 11.70 & 0.50 & 11.80 & 0.50 \\
\hline $\operatorname{Leg}(\%)$ & 29.80 & 0.70 & 29.70 & 0.70 & 30.00 & 0.70 & 30.50 & 0.70 \\
\hline Shoulder (\%) & 21.50 & 0.40 & 21.50 & 0.40 & 21.20 & 0.40 & 22.20 & 0.40 \\
\hline Loin $(\%)$ & 16.90 & 0.50 & 17.70 & 0.50 & 16.90 & 0.50 & 16.80 & 0.50 \\
\hline Breast and flank (\%) & $18.50^{\mathrm{ab}}$ & 0.60 & $17.70^{\mathrm{a}}$ & 0.60 & $20.00^{\mathrm{b}}$ & 0.60 & $18.40^{\mathrm{ab}}$ & 0.60 \\
\hline
\end{tabular}

${ }^{\mathrm{a}, \mathrm{b}}$ : Means within rows with different superscripts are different $(\mathrm{p}<0.05) ;{ }^{1}$ : Total per carcass as half carcass $\times 2$

Table 4: Least square means of proportions (\%) of meat, bone, subcutaneous fat and intramuscular fat in different areas of the carcass of goats in different treatments: (1) basal diet-Control (CN), (2) basal + Vitamin E (VE), (3) basal + Turmeric (TU) and (4) basal + Andrographis Paniculata (AP)

\begin{tabular}{|c|c|c|c|c|c|c|c|c|}
\hline \multirow[b]{3}{*}{ Parameter } & \multicolumn{8}{|c|}{ Treatments } \\
\hline & \multicolumn{2}{|l|}{$\mathrm{CN}$} & \multicolumn{2}{|l|}{ VE } & \multicolumn{2}{|l|}{$\mathrm{TU}$} & \multicolumn{2}{|r|}{$\mathrm{AP}$} \\
\hline & Mean & $\mathrm{Se}$ & Mean & $\mathrm{Se}$ & Mean & $\mathrm{Se}$ & Mean & $\mathrm{Se}$ \\
\hline Treatments & $63.40^{\mathrm{a}}$ & 1.40 & $65.20^{\mathrm{ab}}$ & 1.40 & $64.60^{\mathrm{ab}}$ & 1.40 & $67.80^{\mathrm{b}}$ & $\frac{1.40}{1.40}$ \\
\hline Neck & 73.30 & 2.10 & 73.40 & 2.10 & 72.50 & 2.10 & 70.10 & 2.00 \\
\hline Leg & 71.10 & 1.10 & 74.30 & 1.20 & 72.50 & 1.10 & 72.50 & 1.10 \\
\hline Shoulder & 70.80 & 4.20 & 74.90 & 4.40 & 71.90 & 4.20 & 63.50 & 4.10 \\
\hline Loin & 63.80 & 2.50 & 66.80 & 2.50 & 66.00 & 2.50 & 65.30 & 2.50 \\
\hline Breast and flank & $61.30^{\mathrm{a}}$ & 1.10 & $64.80^{\mathrm{ab}}$ & 1.10 & $65.30^{\mathrm{b}}$ & 1.10 & $64.90^{\mathrm{b}}$ & 1.10 \\
\hline $\begin{array}{l}\text { Bone } \\
\text { litilitis }\end{array}$ & 21.00 & 1.10 & 19.20 & 1.10 & 19.30 & 1.10 & 20.00 & 1.10 \\
\hline Neck & $21.10^{\mathrm{a}}$ & 1.40 & $19.50^{\mathrm{a}}$ & 1.40 & $21.20^{\mathrm{ab}}$ & 1.40 & $24.70^{\mathrm{b}}$ & 1.40 \\
\hline Leg & $22.50^{\mathrm{a}}$ & 0.50 & $22.50^{\mathrm{a}}$ & 0.50 & $20.30^{\mathrm{b}}$ & 0.50 & $21.50^{\mathrm{ab}}$ & 0.50 \\
\hline Shoulder & 20.30 & 0.80 & 18.50 & 0.80 & 19.90 & 0.80 & 20.40 & 0.80 \\
\hline Loin & $27.70^{\mathrm{ab}}$ & 1.60 & $24.80^{\mathrm{a}}$ & 1.60 & $27.20^{\mathrm{ab}}$ & 1.60 & $29.40^{\mathrm{b}}$ & 1.60 \\
\hline Breast and flank & $17.20^{\mathrm{a}}$ & 0.40 & $16.90^{\text {ac }}$ & 0.40 & $15.70^{\mathrm{b}}$ & 0.40 & $16.30^{\mathrm{bc}}$ & 0.40 \\
\hline Subcutaneous fat & 2.95 & 0.43 & 2.18 & 0.39 & 3.19 & 0.42 & 2.21 & 0.41 \\
\hline Neck & 0.62 & 0.08 & 0.73 & 0.08 & 0.63 & 0.08 & 0.74 & 0.08 \\
\hline Leg & 2.05 & 0.38 & 1.68 & 0.37 & 2.46 & 0.39 & 2.46 & 0.38 \\
\hline Shoulder & 3.08 & 0.67 & 2.10 & 0.65 & 3.18 & 0.69 & 2.64 & 0.67 \\
\hline Loin & 0.79 & 0.13 & 0.90 & 0.13 & 0.96 & 0.13 & 0.94 & 0.13 \\
\hline Breast and flank & 10.90 & 0.80 & 9.50 & 0.80 & 10.50 & 0.80 & 9.90 & 0.80 \\
\hline Intermuscular fat & 3.87 & 0.35 & 3.45 & 0.34 & 3.69 & 0.34 & 3.12 & 0.33 \\
\hline Neck & 2.64 & 0.34 & 2.72 & 0.34 & 1.89 & 0.31 & 2.16 & 0.33 \\
\hline Leg & 2.06 & 0.29 & 2.24 & 0.29 & 2.12 & 0.29 & 2.34 & 0.29 \\
\hline Shoulder & 3.55 & 0.71 & 4.04 & 0.71 & 4.25 & 0.72 & 3.59 & 0.71 \\
\hline Loin & 5.16 & 0.64 & 4.02 & 0.64 & 5.26 & 0.64 & 4.09 & 0.64 \\
\hline Breast and flank & $9.67^{\mathrm{a}}$ & 0.72 & $7.12^{\mathrm{b}}$ & 0.71 & $7.71^{\mathrm{ab}}$ & 0.71 & $7.25^{\mathrm{b}}$ & 0.71 \\
\hline
\end{tabular}

a,b,c: Means within rows with different superscripts are different $(\mathrm{p}<0.05)$

Carcass characteristics: Hot and cold carcass weights were not different $(p>0.05)$ between treatments (Table 3). Similarly, there were no differences $(p>0.05)$ in dressing percentage (hot carcass) or in percentages of the cold carcass, heart fat, or channel fat. However, percentages of the mesentery and kidney fat were higher $(\mathrm{p}<0.05)$ for $\mathrm{TU}$ than for AP. The other differences in the percentages of the mesentery and kidney fat among treatments were not significant. The measurements of the mean weights and percent proportions of meat, bone, subcutaneous fat and intermuscular fat were conducted of carcass (Table 3). 
American J. Animal \& Vet. Sci., 5 (1): 33-39, 2010

Table 5: Eye muscle characteristics of goats in different treatments: (1) basal diet-Control (CN), (2) basal + Vitamin E (VE), (3) basal + Turmeric (TU) and (4) basal + Andrographis paniculata (AP)

\begin{tabular}{|c|c|c|c|c|c|c|c|c|}
\hline \multirow[b]{3}{*}{ Parameter } & \multicolumn{8}{|c|}{ Treatments } \\
\hline & \multicolumn{2}{|l|}{$\mathrm{CN}$} & \multicolumn{2}{|l|}{ VE } & \multicolumn{2}{|l|}{ TU } & \multicolumn{2}{|r|}{ AP } \\
\hline & Mean & $\mathrm{Se}$ & Mean & $\mathrm{Se}$ & Mean & $\mathrm{Se}$ & Mean & $\mathrm{Se}$ \\
\hline Eye muscle area $\left(\mathrm{cm}^{2}\right)$ & $10.20^{\mathrm{a}}$ & 0.60 & $11.30^{\mathrm{ab}}$ & 0.50 & $12.10^{\mathrm{b}}$ & 0.60 & $12.00^{\mathrm{b}}$ & 0.50 \\
\hline Eye muscle length $(\mathrm{mm})$ & 46.60 & 1.70 & 49.50 & 1.60 & 50.50 & 1.70 & $50.2^{0}$ & 1.60 \\
\hline Eye muscle depth (mm) & $26.00^{\mathrm{a}}$ & 1.30 & $30.90^{\mathrm{b}}$ & 1.20 & $31.60^{\mathrm{b}}$ & 1.30 & $30.00^{\mathrm{b}}$ & 1.20 \\
\hline Eye muscle back fat (mm) & $1.21^{\mathrm{a}}$ & 0.06 & $1.11^{\mathrm{a}}$ & 0.06 & $1.29^{\mathrm{a}}$ & 0.06 & $0.93^{\mathrm{b}}$ & 0.06 \\
\hline
\end{tabular}

${ }_{\mathrm{a}, \mathrm{b}}$ : Means within rows with different superscripts are different $(\mathrm{p}<0.05)$

These results showed that weight of carcass lean tissue was lower $(\mathrm{p}<0.05)$ for $\mathrm{CN}$ than for TU and $\mathrm{AP}$, with an intermediate value for VE ( $p>0.05)$. The weight of the intermuscular fat was higher $(\mathrm{p}<0.05)$ for the TU than for the AP treatment but the differences between other treatments in weight and percentages were not significant. Also, differences between treatments in bone and subcutaneous fat measurements were not significant. The differences in the percentage of weights of different carcass cuts were not significant for the neck, leg, shoulder and loin, but for the breast and flank cut it was higher $(\mathrm{p}<0.05)$ for TU than for VE. The proportion of lean tissue in the whole carcass (Table 4) was higher for A P than for $\mathrm{CN}$, with intermedia values for VE and TU ( $>>0.05)$. The level of lean tissue in the breast and flank cut was higher $(p<0.05)$ for TU and AP than for $\mathrm{CN}$. The level of carcass bone was not different ( $>>0.05)$ among treatments. The level of bone in the neck cut was higher $(\mathrm{p}<0.05)$ for AP than for $\mathrm{CN}$ and VE. Similarly, the level of bone in the leg cut was lower $(\mathrm{p}<0.05)$ for $\mathrm{TU}$ than for $\mathrm{CN}$ and VE. The level of bone in the loin cut for the AP treatment was higher than for the VE treatment ( $<<0.05)$. The level of bone in the breast and flank cut was higher $(\mathrm{p}<0.05)$ for $\mathrm{CN}$ than for TU. Levels of subcutaneous and intermuscular fat in neck, leg and loin cuts were similar among treatments. However, the level of subcutaneous fat was lower $(p<0.05)$ in the shoulder cut for the VE treatment than for the AP treatment. The level of intermuscular fat for $\mathrm{CN}$ was greater $(p<0.05)$ than that for AP. Differences among treatments in length of the longissimus muscle were not significant (Table 5). However, area of the longissimus muscle was less $(\mathrm{p}<0.05)$ for $\mathrm{CN}$ than for TU and AP. Depth of the longissimus muscle was lowest among treatments $(\mathrm{p}<0.05)$ for $\mathrm{CN}$. The thickness of fat covering the longissimus muscle was lowest among treatments $(\mathrm{p}<0.05)$ for AP.

\section{DISCUSSION}

Compared to the basal diet the best apparent improvement in the growth performance of goats in the present experiment was achieved with the dietary supplement of turmeric powder, while the growth performance of goats fed the vitamin E supplemented diet was similar to the goats receiving the basal diet. This is in agreement with Yang et al. (2002) who reported no effect of the dietary vitamin E supplement on the growth performance, carcass weight or fatness of cattle. Intermuscular fat in the breast and flank cut decreased in the carcass and the increased depth of the longissimus muscle due to the vitamin E supplement; the other indicators of the carcass quality in the present experiment were similar for the $\mathrm{CN}$ and the $\mathrm{VE}$ treatments. Similarly, Eikelenboom et al. (2000) reported that dietary vitamin $\mathrm{E}$ treatment had not affected the live weight before slaughter, hot carcass weight and the dressing percentage in goats. Results of other studies with Boer and Spanish goats (Mahgoub et al., 2004; Mahgoub and Lu, 1998; Turner et al., 2005; Wildeus et al., 2007) showed higher mean dressing percentage than in the present experiment, but this was probably due to the small size of the local Kacang goat in comparison with the meat type Boer or Spanish goats. Others reported the dressing percentage in the range of $43.9-55.7 \%$ in Boar, South Africa indigenous and Angora goats (Tshabalalaa et al., 2003; Lupton et al., 2008), which is similar to that in the present experiment (46.7-49.9 $\%)$. Although the goats fed the Andrographis paniculata powder-supplemented diet produced significantly better FE than the goats fed the basal diet, this appeared to be at the expense of decreased feed intake. The reason for the relatively low feed intake in the AP treatment is not exactly known, but it could be related to lower palatability of the AP diet in comparison with other diets used in the present experiment. In general, the AP treatment produced more desirable leaner carcass with higher proportion of meat and better longissimus muscle cut than the $\mathrm{CN}$ treatment. However, further research is required to determine the cause of lower feed intake before Andrographis paniculata powder could be recommended as a feed additive. The apparent growth 
performance was better for the turmeric-supplemented goats than for the control goats and their daily weight gain of $102 \mathrm{~g} \mathrm{day}^{-1}$ was approximately equal to that reported for Spanish goats $\left(103 \mathrm{~g} \mathrm{day}^{-1}\right)$ fed an alfalfa hay-based diet supplemented with a concentrate at $0.5 \%$ of body weight (Turner et al., 2005). The above gains were better than that of $96 \mathrm{~g}$ in the castrated Angora kids raised in a feedlot system (Lupton et al., 2008) or $84 \mathrm{~g}$ obtained for the present basal diet. In addition, there was in general more meat in the carcass with much larger longissimus muscle in the turmeric supplemented goats than in the control goats in the present experiment.

\section{CONCLUSION}

On the basis of the present results it can be concluded that dietary antioxidants from natural herbs such as Andrographis paniculata have potential for improved feed efficiency and reduced meat fat and internal fat in the carcass. Addition of turmeric increased average daily gain and feed intake.

This study indicates that feeding dietary herbs and synthetic antioxidants have potential for improvement of growth and carcass characteristics of goats. Particularly AP effect on meat fat and internal body fat. Addition of turmeric increased gain and feed intake. Furthermore, local herbal antioxidants are available and they could improve meat quality that finally helps to world human health.

\section{ACKNOWLEDGEMENT}

This study was supported the Sciencefund Research Grant 05-01-04-SSF0288 under the Ministry of Science, Technology and Innovation, Malaysia. The visit of Dr. M. Ivan at the University Putra Malaysia was sponsored by the Academy of Sciences Malaysia-Ministry of Science, Technology and Innovation under the Brain Gain Malaysia-Distinguished Visitor Program.

\section{REFERENCES}

Alexandre, G., S. Asselin de Beauville, E. Shitalou and M.F. Zebus, 2008. An overview of the goat meat sector in Guadeloupe: Conditions of production, consumer preferences, cultural functions and economic implications. Livestock Res. Rural Dev., 20: $1-14$.

http://www.cipav.org.co/lrrd/lrrd20/1/alex20014.htm

Almeida, A.M., L.M. Chwalbach, H.O. Waal, J.P.C. Greyling and L.A. Cardoso, 2006. The effect of supplementation on productive performance of boer goat bucks fed winter veld hay. Trop. Anim. Health Prod., 38: 443-449.
AOAC., 1990. Official Methods of Analysis. Association of Official Analytical Chemists, Washington, DC.

Bock, B.J., D.L. Harmon, R.T. Brandt and J.E. Schneider, 1991. Fat source and calcium level effects on finishing steer performance, digestion and metabolism. J. Anim. Sci., 69: 2211-2224.

Branscome, J. and C. Jesseman, 1999. ArC software download and user guide page. http://www.concentric.net/ Jbrans/ArC/download. htm

Buckley, D.J., P.A. Morissey and J.I. Gray, 1995. Influence of dietary vitamin $\mathrm{E}$ on the oxidative stability and quality of pig meat. J. Anim. Sci., 73: 3122-3130.

Chew, B.P., 1995. Antioxidant vitamins affect food animal immunity and health. J. Nutr., 125: 1804-1808.

Colomer-Rocher, F., A.H. Kirton, G.J.K. Merces and D.M. Duganzich, 1992. Carcass composition of New Zealand Saanen goats slaughtered at different weights. Small Rumin Res., 7: 161-173.

Devendra, C. and M. Burns, 1983. Goat Production in the Tropics. In: Commonwealth Agricultural Bureaux, Slough. UK., P: 183.

Dhanda, J.S., D.G. Taylor and P.J. Murray, 2003. Part 1. growth, carcass and meat quality parameters of male goats: Effects of genotype and live weight at slaughter, Small Rumin Res., 50: 57-66.

Eikelenboom, G., A.H. Hoving-Bolink, I. Kluitman, J.H. Houben and R.E. Klont, 2000. Effect of dietary vitamin $\mathrm{E}$ supplementation on beef color stability. Meat Sci., 54: 17-22.

Farid, A., 1991. Carcass physical and chemical composition of three fat-tailed breeds of sheep. Meat Sci., 29: 109-120.

Gupta, K.K. and S.C. Taneja, 1983. Flavonoids of Anderographis paniculata. Phyfochemrsrry, pnated 3rd great bntam. Pergamon Press Ltd., 22: 314-315.

Jarukamjorn, K. and N. Nemoto, 2008. Pharmacological aspects of Andrographis paniculata on health and its magor diterpenoid constituent andrographolide. J. Health sci., 54: 370-381.

Kamdem, R.E., S. Sang and C.T. Ho, 2002. Mechanism of the superoxide scavenging activity of neoandrographolide-a natural product from andrographis paniculata nees. J. Agric. Food Sci., 50: 4662-4665.

Kirton, A.H., 1988. Characteristics of goat meat including carcass quality and methods of slaughter. Proceeding of the Workshop on goat meat production in Asia, Mar. 13-18, Tando Jam, Pakistan, pp: 87-99. 
Kosum, N., A. Alcicek, T. Taskin and A. Onenc, 2003. Fattening performance and carcass characteristics of Saanen and Bornova male kids under an intensive management system. Czech J. Anim. Sci., 48: 379-386.

Lupton, C.J., J.E. Huston, J.W. Hruska, B.F. Craddock and F.A. Pfeiffer et al., 2008. Comparison of three systems for concurrent production of high quality mohair and meat from angora male kids. Small Rumin. Res., 74; 64-71.

Mahgoub, O., I.T. Kadim, N.M. Al-Saqry and R.M. Al-Busaidi, 2004. Effects of body weight and sex on carcass tissue distribution in goats. Meat Sci., 67: 577-585.

Mahgoub, O. and C.D. Lu, 1998. Growth, body composition and carcass tissue distribution in goats of large and small sizes. Small Rumin. Res., 27: 267-278.

McDowell, L.R., S.N. Williams, N. Hidiroglou, C.A. Njeru and G.M. Hill et al., 1996. Vitamin E supplementation for the ruminant. Anim. Feed Sci. Technol., 60: 273-296.

Miquel, J.B.A., J.M. Sempere, J. Diaz-Alperi and C.A. Ramirez, 2002. The curcuma antioxidants: Pharmacological effects and prospects for future clinical use. A review. Arch. Gerontol. Geriatrics, 34: 37-46.

Mishra, S.K., N.S. Sangwan and R.S. Sangwan, 2007. Andrographis paniculata (Kalmegh): A review. Pharmacog. Rev., 1: 283-298.

Morrissey, P.A., P.J.A. Sheehy, K. Galvin, J.P. Kerry and D.J. Buckley, 1998. Lipid stability in meat and meat products. Meat Sci., 49: 73-86.

Phengvichith, V. and I. Ledin, 2007. Effect of a diet high in energy and protein on growth, carcass characteristics and parasite resistance in goats. Trop. Anim. Health Prod., 39: 59-70.

Rubya, A.J., G. Kuttan, K. Dinesh Babub, K.N. Rajasekharanb and R. Kutta, 1995. Antitumor and antioxidant activity of natural curcuminoids. Cancer Lett., 94: 79-83.
Saker, K.E., J.H. Fike, H. Veit and D.L. Ward, 2004. Brown seaweed-(TascoTM) treated conserved forage enhances antioxidant status and immune function in heat-stressed weather lambs. J. Anim. Physiol. Anim. Nutr., 88: 122-130.

Sharma, O.P., 1976. Antioxidant activity of curcumin and related compounds. Biochem. Pharmacol., 25: 1811-1812.

Tipakorn, N., W. Tartrakoon, G. Thinggaard, U. Ter Meulen, 2003. Antibacterial activity of Andrographis paniculata leaf extracts. J. Agric. Rural Dev. Trop. Subtrop., 80: 187-194.

Toda, S., T. Miyase, H. Arichi, H. Tanizawa and Y. Takino, 1985. Natural antioxidants. III. Antioxidative components isolated from rhizome of Curcuma longa L. Chem. Pharm. Bull., 33: 1725-1728.

Tshabalalaa, P.A., P.E. Strydom, E.C. Webb and H.L. Kocka, 2003. Meat quality of designated South African indigenous goat and sheep breeds. Meat Sci., 65: 563-570.

Turner, K.E., S. Wildeus and J.R. Collins, 2005. Intake, performance and blood parameters in young goats offered high forage diets of lespedeza or alfalfa hay. Small Rumin. Res., 59: 15-23.

Webb, E.C., N. Casey and L. Simela, 2005. Goat meat quality. Small Rumin. Res., 60: 153-166.

Wildeus, S., J.M. Luginbuhl, K.E. Turner, Y.L. Nutall and J.R. Collins, 2007. Growth and carcass characteristics in goat kids fed grass-and alfalfahay-based diets with limited concentrate supplementation. Sheep Goat Res. J., 22: 15-19.

Yang, A., M.J. Brewster, M.C. Lanari and R.K. Tume, 2002. Effect of vitamin E supplementation on atocopherol and b-carotene concentrations in tissues from pasture and grain-fed cattle. Meat Sci., 60: 35-40.

Zhang, X.F. and B.K.H. Tan, 2000. Antihyperglycaemic and antioxidant properties of Andrographis paniculata in normal and diabetic rats. Clin. Exp. Pharmacol. Physiol., 27: 358-363. 